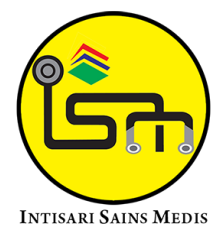

Published by Intisari Sains Medis

\title{
Penanganan kandidiasis orofaring pada pasien Human Immunodeficiency Virus/Acquired Immunodeficiency Syndrome (HIV/AIDS) dengan nilai CD4 dibawah $10 \mathrm{sel} / \mu \mathrm{L}$ : laporan kasus
}

\author{
Winda Dwi Malinda Masuku", Dian Angriany ${ }^{1}$, Saka Winias², Adiastuti Endah Parmadiati²
}

${ }^{1}$ Residen Program Pendidikan Dokter Gigi Spesialis IImu Penyakit Mulut, Fakultas Kedokteran Gigi, Universitas Airlangga, Surabaya, Indonesia; 2Departemen Ilmu Penyakit Mulut, Fakultas Kedokteran Gigi, Universitas Airlangga, Surabaya, Indonesia;

\footnotetext{
*Korespondensi:

Winda Dwi Malinda Masuku;

Residen Program Pendidikan Dokter Gigi Spesialis IImu Penyakit Mulut, Fakultas Kedokteran Gigi, Universitas Airlangga, Surabaya, Indonesia; winda.drg@gmail.com
}

Diterima: 03-06-2021

Disetujui: 22-08-2021

Diterbitkan: 31-08-2021

\section{ABSTRACT}

Background: The oral manifestation of Human Immunodeficiency Virus/Acquired Immunodeficiency Syndrome (HIV/AIDS) is an important indicator because it is a disorder that usually appears first when the immune system is suppressed. Oropharyngeal candidiasis is an opportunistic infection that most often occurs in people suffering from HIV infection or AIDS. It is also an important marker in immunosuppressed states with CD4 values below 200 cells $/ \mathrm{mm}^{3}$. This case study aims to evaluate the treatment of oropharyngeal candidiasis in patients with HIV/AIDS with CD4 values below 10 cells $/ \mu \mathrm{L}$

Case Presentation: A 30-year-old man complained of a thick and uncomfortable feeling in the entire oral cavity felt since 4 months ago. Clinical examination revealed multiple pseudomembranous, which were

removed and left a reddish area at the base of most of the oral cavity to the pharynx. The results of the fungal examination showed that the hyphae were not insulated with the results of candida albicans culture, and the absolute $C D 4$ value was 9 cells/4l. On the second visit, the patient admitted that he was HIV positive by bringing a reactive result on the 3-method anti-HIV examination conducted 3 months earlier. This case was handled by administering an antiseptic mouthwash, topical and systemic antifungal, and referred to the IHAN RSUA polyclinic for ARV therapy.

Conclusion: The successful treatment of oropharyngeal candidiasis, in this case, depends on integrated therapy between dentists and internists as well as patient compliance in following doctor's instructions.

Keywords: Oropharyngeal candidiasis, Candida albicans, Pseudomembranous candidiasis, HIV, AIDS, CD4.

Cite This Article: Masuku, W.D.M., Angriany, D., Winias, S., Parmadiati, A.E. 2021. Penanganan kandidiasis orofaring pada pasien Human Immunodeficiency Virus/Acquired Immunodeficiency Syndrome (HIV/AIDS) dengan

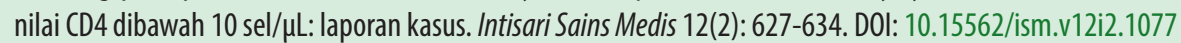

\section{ABSTRAK}

Latar Belakang: Manifestasi oral Human Immunodeficiency Virus/Acquired Immunodeficiency Syndrome (HIV/AIDS) menjadi indikator penting karena merupakan kelainan yang biasanya muncul pertama kali saat kondisi imun tersupresi. Kandidiasis orofaring merupakan suatu infeksi oportunistik yang paling sering terjadi pada orang yang menderita infeksi HIV atau AIDS. Hal ini juga disadari sebagai suatu pertanda penting pada keadaan imunosupresi dengan nilai CD4 dibawah $200 \mathrm{sel} / \mathrm{mm}^{3}$. Laporan kasus ini bertujuan untuk mengevaluasi penanganan kandidiasis orofaring pada pasien (HIV/AIDS) dengan nilai CD4 dibawah 10 $\mathrm{sel} / \mu \mathrm{L}$

Presentasi Kasus: Seorang laki-laki berusia 30 tahun mengeluhkan rasa tebal dan tidak nyaman pada seluruh rongga mulut yang dirasakan sejak 4 bulan yang lalu. Pemeriksaan klinis ditemukan pseudomembran multipel yang dapat dihapus dan meninggalkan area kemerahan di dasarnya pada hampir seluruh rongga mulut hingga ke faring. Hasil pemeriksaan jamur menunjukkan hyphae tidak bersekat dengan hasil biakan candida albicans, dan nilai CD4 absolut 9 cell/ $\mu$ l. Kunjungan kedua Pasien mengakui sebagai pengidap HIV dengan membawa hasil reaktif pada pemeriksaan anti-HIV 3 metode yang telah dilakukan 3 bulan sebelumnya. Penanganan kasus ini dengan pemberian antiseptik kumur, anti jamur topikal dan sistemik serta dirujuk ke poli IHAN RSUA untuk melakukan terapi ARV. Kesimpulan: Keberhasilan penanganan kandidiasis orofaringeal pada kasus ini bergantung pada terapi 
yang terintegrasi antara dokter gigi dan dokter penyakit instruksi dokter.

dalam serta kepatuhan pasien dalam mengikuti

Kata kunci: Kandidiasis Orofaring, Candida albicans, Kandidiasis Pseudomembran, HIV, AIDS, CD4.

Sitasi Artikel ini: Masuku, W.D.M., Angriany, D., Winias, S., Parmadiati, A.E. 2021. Penanganan kandidiasis orofaring pada pasien Human Immunodeficiency Virus/Acquired Immunodeficiency Syndrome (HIV/AIDS) dengan nilai CD4 dibawah 10 sel/ $\mu$ L: laporan kasus. Intisari Sains Medis 12(2): 627-634. D0I: 10.15562/ism.v12i2.1077

\section{PENDAHULUAN}

Kandidiasis oral adalah salah satu infeksi jamur pada mukosa mulut yang sering terjadidan disebabkan oleh spesies Candida terutama Candida albicans. ${ }^{1}$ Kandidiasis yang paling sering terjadi di antara pasien immunocompromised dengan jumlah sel Cluster of Differentiation 4 (CD4) rendah di bawah $200 \mathrm{sel} / \mathrm{mm}^{3}$ adalah Kandidiasis Orofaring dan/atau kandidiasis esofageal. ${ }^{2}$ Kandidiasis orofaring biasanya hadir beberapa bulan bulan atau tahun sebelum infeksi oportunistik berat lainnya dan dapat menunjukkan kehadiran atau perkembangan penyakit Human Immunodeficiency Virus/Acquired Immunodeficiency Syndrome (HIV/ AIDS). ${ }^{3}$

Indonesia merupakan negara dengan jumlah kasus HIV/AIDS yang tinggi. Terdapat 36,7 juta penderita HIV/AIDS yang dilaporkan di Indonesia pada tahun 2016. Kasus baru ditemukan pada 1,6 juta penderita dari tahun 2010 hingga 2016. Kandidiasis oral merupakan gejala klinis yang ditemukan pada $50-95 \%$ penderita HIV/AIDS. ${ }^{5}$ Kandidiasis oral pada pasien HIV sangat terkait dengan jumlah CD4 yang rendah, $90 \%$ terjadi pada pasien sebelum menggunakan Highly Active Antiretroviral Therapy (HAART) atau yang terlambat memulai terapi antiviral. ${ }^{6}$ Pada pasien HIV-positif, kolonisasi dan penyakit di rongga mulut dan permukaan mukosa lainnya sering ditemukan, terutama dengan C. albicans, yang meningkat secara cepat seiring dengan perkembangan penyakit. ${ }^{7}$

Candida albicans muncul dalam empat bentuk: Kandidiasis pseudomembran, kandidiasis hiperplastik, kandidiasis eritematosa, dan cheilitis angular. Pasien mungkin menunjukkan satu atau kombinasi dari salah satu presentasi ini. Pada pasien dengan AIDS yang berat, bentuk Kandidiasis pseudomembran adalah yang paling sering dilaporkan. ${ }^{8}$

Berdasarkan pemaparan di atas, maka laporan kasus ini bertujuan untuk melaporkan tentang kasus kandidiasis orofaring pada seorang laki- laki 30 tahun dengan HIV/AIDS dengan jumlah CD4 yang sangat rendah beserta penanganannya.

\section{LAPORAN KASUS}

Seorang Laki-laki berusia 30 tahun, belum menikah, datang ke Rumah Sakit Gigi dan Mulut (RSGM) Universitas Airlangga dengan keluhan rasa tebal dan tidak nyaman pada seluruh rongga mulut. Keluhan dirasakan sejak kurang lebih 4 bulan sebelumnya. Pada awalnya lapisan keluhan ini dirasakan hanya sedikit, berupa lapisan berwarna putih di pipi kiri bagian dalam kemudian meluas ke langit-langit, lidah dan gusi. Satu bulan sebelumnya keluhan dirasakan semakin meluas dan memberikan rasa ketidaknyamanan pada pasien. Keluhan ini akhirnya diobati dengan menggunakan nystatin yang dibeli sendiri di apotik, dan digunakan dengan cara diteteskan pada lidah sehari satu kali, dan menghabiskan 1 botol. jamur dirasakan berkurang namun kemudian tumbuh lagi. Sehingga pengobatan tidak dilanjutkan lagi. Keluhan lain yang dirasakan adalah sakit saat menelan makanan dan sesak napas. Kurang lebih 1 minggu terakhir ini pasien mengalami diare dan telah minum obat yang dibeli sendiri di apotik dan masih diare hingga saat ini. Terdapat penurunan berat badan dari berat badan awal $68 \mathrm{~kg}$ menjadi 43 $\mathrm{kg}$. Penurunan sebanyak $25 \mathrm{~kg}$ dirasakan dalam waktu 6 bulan terakhir. Pasien menyangkal menggunakan narkoba dan menyangkal sex bebas, Nafsu makan berkurang sejak keluhan di rongga mulut dirasakan, dan pasien merasa badan lemah dan lemas. 1 tahun terakhir 6 kali dirawat di beberapa rumah sakit dengan diagnosis radang usus besar, gastritis, batu ginjal, diare, dan sesak napas. Pasien diketahui memiliki berat badan $43 \mathrm{~kg}$, tinggi badan sebesar $168 \mathrm{~cm}$, dan Indeks Massa Tubuh (IMT) sebesar $15,2 \mathrm{~kg} / \mathrm{m}^{2}$ atau kategori underweight.

Riwayat kesehatan radang usus besar, gastritis, dan batu ginjal kurang lebih pada 1 tahun terakhir, kemudian pada 1 minggu terakhir demam, dan diare, sejak september hingga oktober pernah dirawat 6x di RS Paru, RS Soewandi dan RS Unair karena keluhan demam, diare dan sesak napas. Obat-obatan yang rutin dikonsumsi tidak ada, dan obat-obatan yang dikonsumsi non rutin antara lain Jamu beras kencur, Madu, dan nystatin. Riwayat dalam keluarga adalah ayah menderita hipertensi, kakak menderita gastritis.

Pemeriksaan klinis ekstra oral yaitu wajah simetris, pipi dan daerah perioral terdapat deskuamasi, Multipel, berwarna putih, bentuk dan ukuran bervariasi, batas difuse, tepi ireguler, jaringan sekitar kemerahan. Bibir atas dan bawah, mukosa bibir berwarna pucat, dengan deskuamasi,

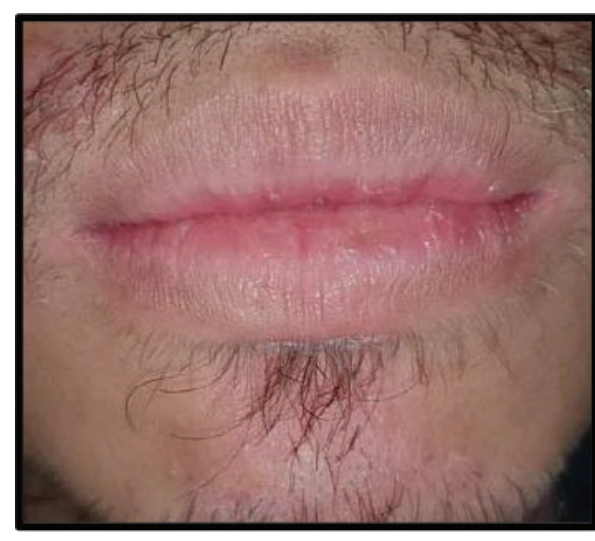

Gambar 1. Pemeriksaan extraoral teradapat deskuamasi pada kulit daerah perioral serta mukosa bibir. 

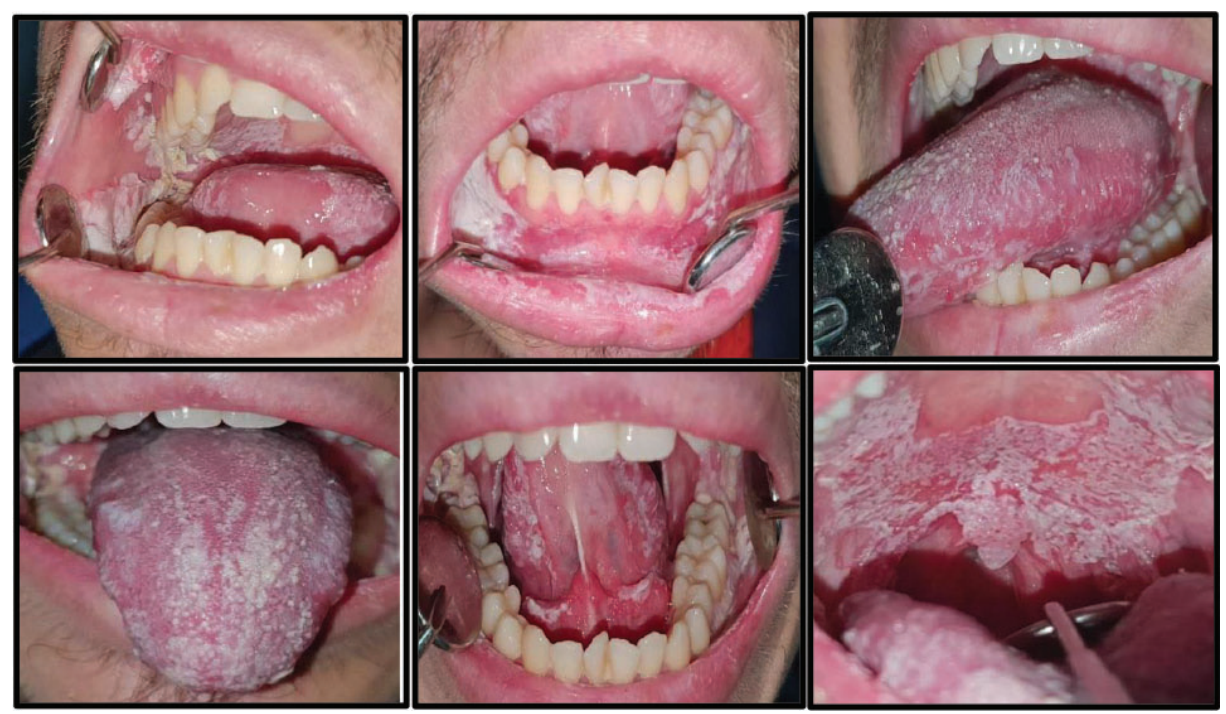

Gambar 2. Pemeriksaan intraoral pasien pada kunjungan pertama dengan pseudomembran multipel, bentuk bervariasi, berwarna putih, batas jelas, dan tepi ireguler.

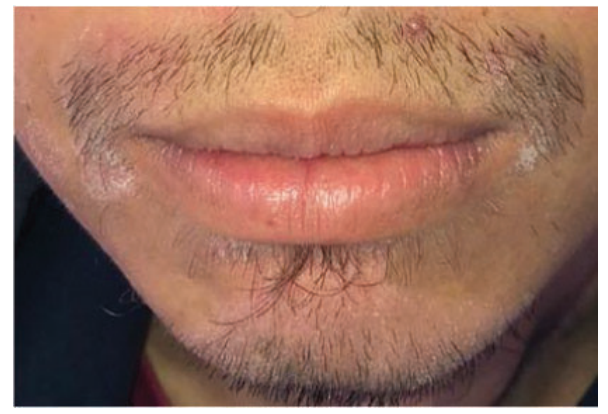

Gambar 3. Gambaran ekstra oral kunjungan kedua.

multipel, berwarna putih, bentuk bervariasi, tepi ireguler, batas difuse, permukaan kasar dan jaringan sekitar kemerahan (Gambar 1). Pemeriksaan kelenjar submandibularis kiri dan kanan, teraba, kenyal dan sakit.

Pemeriksaan klinis intra oral ditemukan Pseudomembran, multipel, bentuk bervariasi, berwarna putih, batas jelas, tepi ireguler, permukaan halus, daerah sekitar kemerahan, dapat dikerok, meninggalkan area kemerahan, dan terasa tidak nyaman pada mukosa labial RA dan $\mathrm{RB}$, mukosa labial fold RA dan RB, mukosa sudut bibir, mukosa bukal dextra dan sinistra, mukosa bukal fold dekstra dan sinistra pada RA dan $\mathrm{RB}$, gingiva anterior RA, gingiva posterior RA \& RB, lidah dorsal dan lateral, lidah dorsal, ventral dan lateral, dasar mulut, palatum durum, palatum molle, uvula, dan tonsil (Gambar 2).

Berdasarkan pemeriksaan subjektif dan objektif pada pasien tersebut, diagnosis sementara yang dibuat adalah Kandidiasis orofaring dengan diagnosis banding coated tongue dan leukoplakia. Tatalaksana meliputi tindakan medis yaitu debridement dengan larutan saline dan kasa steril, serta peresepan obat kumur povidone iodine $1 \%$ digunakan $4 \mathrm{x}$ sehari sebanyak $10 \mathrm{ml}$ dengan jeda 30 menit kemudian dilanjutkan dgn menggunakan obat anti jamur Nystatin oral suspension yang digunakan $4 \mathrm{x}$ sehari sebanyak $4 \mathrm{ml}$ dengan cara diteteskan pada dorsum lidah, kemudian disebarkan merata ke seluruh rongga mulut kemudian ditelan. Dan peresepan ekstrak echinacea $1 x$ sehari. Pemberian rujukan ke laboratorium mikrobiologi untuk pemeriksaan Direct smear $\mathrm{KOH}$ dan kultur jamur untuk menegakkan diagnosis serta rujukan ke patologi klinik untuk pemeriksaan darah lengkap, hitung jenis leukosit, fungsi hati, fungsi ginjal, dan CD4.

Komunikasi, Informasi, dan Edukasi (KIE) meliputi mengkomunikasikan ke pasien tentang kemungkinan penyakitnya yaitu Acute Pseudomembranous Candidiasis, yang kemungkinan disebabkan oleh karena jamur Candida albicans, yang dapat tumbuh karena daya tahan tubuh pasien sedang turun, bisa disebabkan oleh karena beberapa penyakit yang masih harus diperiksa lebih lanjut. Informasikan bahwa diperlukan pemeriksaan penunjang ke Patologi Klinik yaitu pemeriksaan darah lengkap, hitung jenisleukosit, SGOT,SGPT, BUN kreatinin, CD4, dan pemeriksaan penunjang ke laboratorium mikrobiologi jamur untuk pemeriksaan $\mathrm{KOH}$ dan kultur jamur untuk menegakkan diagnosis. Edukasi penggunaan obat kumur yang digunakan nanti setelah dilakukan pemeriksaan jamur dilakukan yaitu berupa obat kumur povidone iodine 1\% digunakan $4 \mathrm{x}$ sehari dan anti jamur nystatin yang digunakan $4 \mathrm{x}$ sehari $(3 \mathrm{x}$ setelah makan dan $1 \mathrm{x}$ sebelum tidur) dan digunakan secara kumur telan. dan diberikan jarak 30 menit - 1 jam diantara kedua obat. Edukasi untuk tidak makan, minum dan berkumur selama 30 menit setelah aplikasi obat. Edukasi untuk cukup istirahat dan makanan makanan yang sehat dan bergizi serta memperbanyak konsumsi buah sayur. Edukasi menjaga Oral Hygiene meliputi menggosok gigi minimal $2 \mathrm{x}$ per hari. Edukasi dan memotivasi pasien jika keluhan yang dirasakan bisa sembuh atau berkurang jika mengikuti anjuran dan percaya serta terbuka tentang penyakitnya kepada operator.

Kunjungan kedua yaitu 7 hari setelah kunjungan pertama, Keluhan pada rongga mulut dirasakan masih ada yaitu mulut terasa kering, tidak nyaman, dan sulit menelan. Pasien merasa lemah, dan diare. Pemeriksaan darah lengkap, CD4, dan pemeriksaan jamur, telah dilakukan, dengan hasil terlampir. obat nystatin dan povidone iodine digunakan tidak rutin karena merasa mual, muntah dan lemas hanya digunakan $1 \mathrm{x}$ sehari dan sudah dihentikan sejak 2 hari yang lalu. Pasien merasa setiap menggunakan obat kumur pasien merasa mual muntah sehingga menghentikan penggunaannya. Ekstrak echinacea dikonsumsi $1 \mathrm{x}$ sehari. sejak dilakukan pemeriksaan darah pasien merasa sangat lemah, dan pasien baru mengakui bahwa pada bulan oktober 2019 pernah diberikan obat ARV (Zidovudine, lamivudine, 3tc dan Nevirapine) saat pasien masuk di UGD RS UNAIR yang hanya digunakan saat berada di UGD saja selama 3 hari, setelah keluar dari UGD 


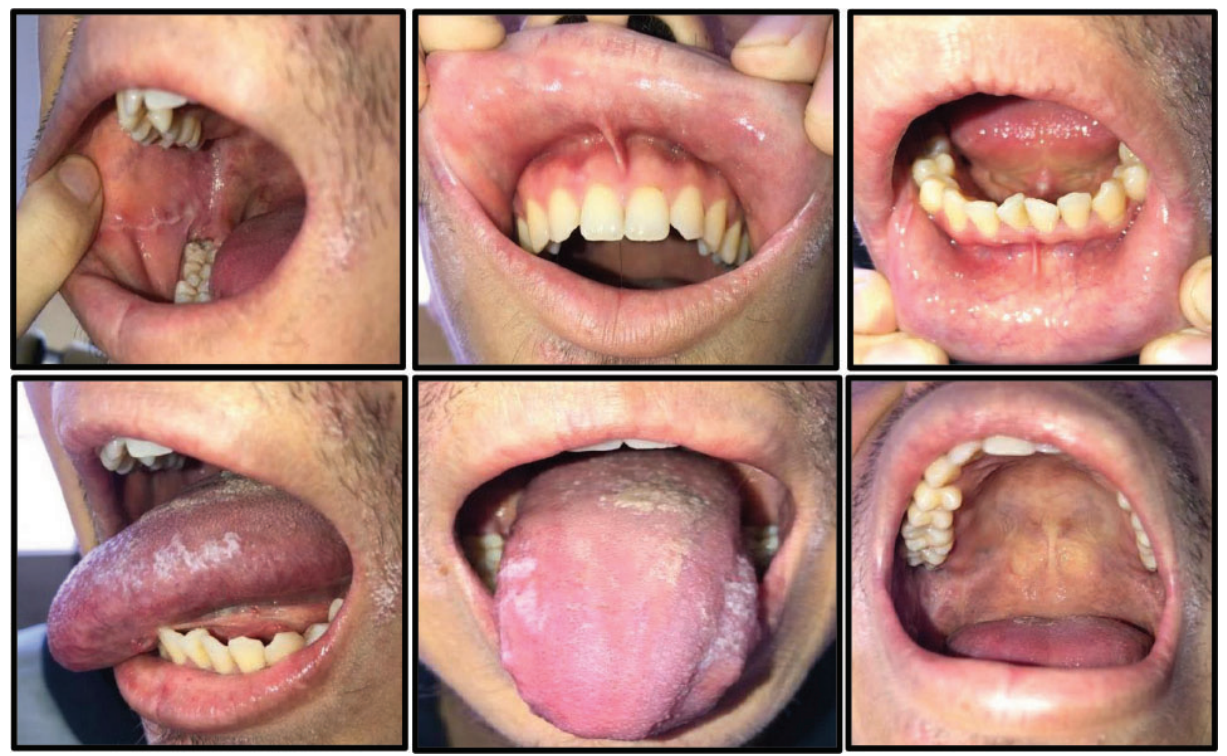

Gambar 4. Pemeriksaan intra oral kunjungan kedua dengan perbaikan kondisi klinis pasien.
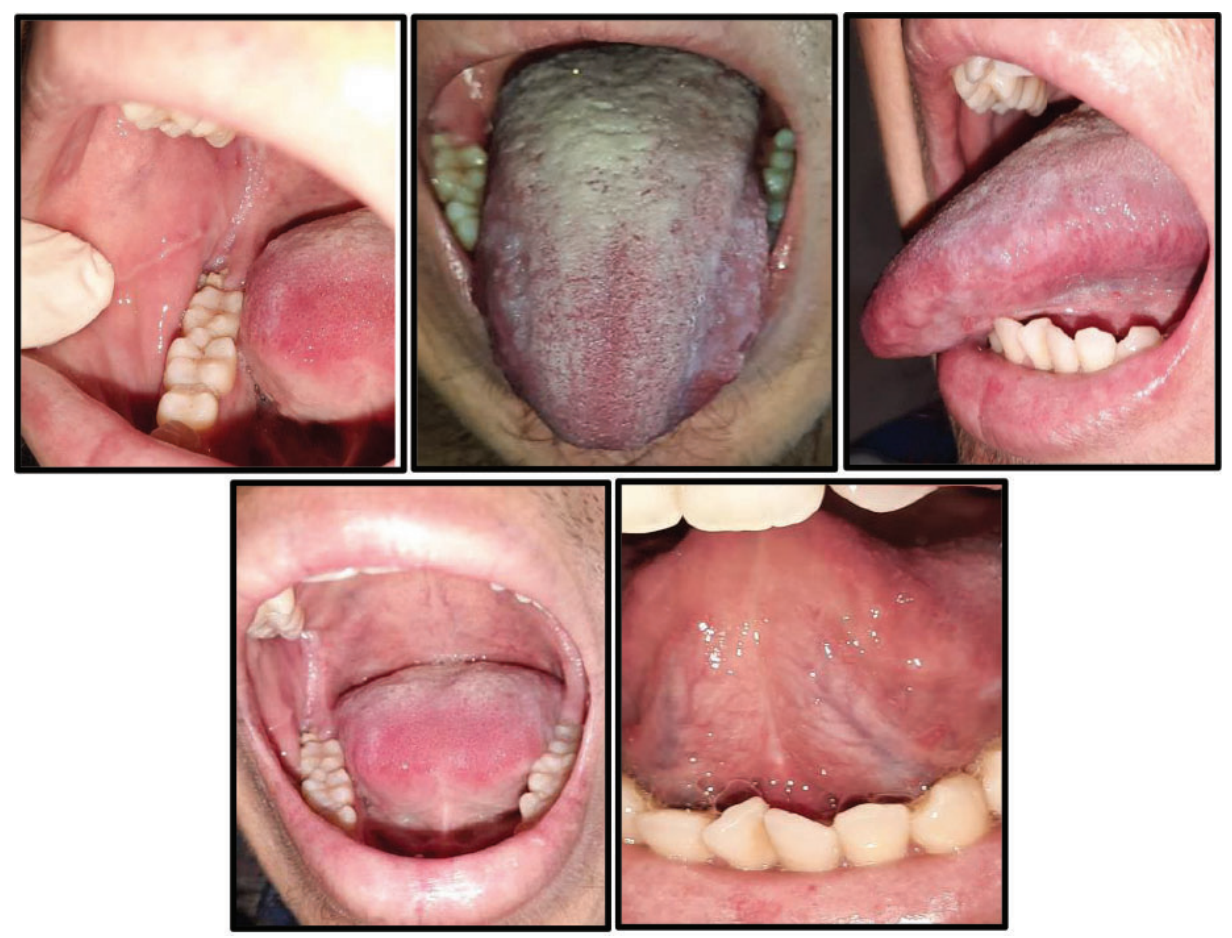

Gambar 5. Pemeriksaan intra oral kunjungan ketiga

pasien tidak mengkonsumsi lagi hingga saat ini. Hasil pemeriksaan HIV yang pernah dilakukan 3 bulan yang lalu juga turut dibawa oleh pasien. Pasien masih belum yakin bahwa hasil pemeriksaan HIV tersebut benar dan masih menyangkal positif HIV walaupun membawa hasil pemeriksaan. Pasien masih merasa bahwa sakit nya saat ini oleh karena sebab lain selain HIV oleh karena itu obat-obatan ARV tersebut tidak mau diminum. Pasien mengaku bahwa sejak mulai sakit-sakitan pasien sering berobat keluar kota dan mencari pengobatan alternatif, ke orang pintar, dan dirasakan membaik setelah pengobatan alternatif selama 1 bulan di kalimantan. Pasien juga sejak 2 hari terakhir mengkonsumsi Java herbal pil.

Pada Pemeriksaan klinis ekstra oral masih ditemukan deskuamasi, multipel, berwarna putih, bentuk dan ukuran bervariasi, batas difuse, tepi ireguler, jaringan sekitar kemerahan, tidak nyeri, terasa kering.pada daerah kulit wajah, pipi, dan perioral. pemeriksaan kelenjar submandibularis kiri dan kanan, teraba, lunak dan sakit (Gambar 3).

Pemeriksaan klinis intraoral ditemukan bahwa pada mukosa bukal sinistra, mukosa bukal fold RB posterior, lidah dorsal dan lateral, serta palatum molle masih terdapat Pseudomembran, multipel, bentuk bervariasi, berwarna putih, batas jelas, tepi ireguler, permukaan halus, daerah sekitar kemerahan, dapat dikerok, tidak nyeri. Sedangkan pada mukosa labial RA \& RB, Mukosa labial fold RA \& RB, Mukosa sudut bibir, Mukosa bukal dextra, Gingiva anterior RA, Gingiva Posterior RA \& RB, Dasar mulut, Palatum durum, Uvula dan Tonsil sudah tidak terdapat abnormalitas (Gambar 4). Adapun hasil pemeriksaan laboratorium dan interpretasinya terdapat pada Tabel 1.

Berdasarkan pemeriksaan klinis dan hasil lab yang telah didapatkan maka kami menetapkan diagnosis yaitu Kandidiasis orofaring dan perawatan yang dilakukan adalah yaitu debridemen dengan larutan saline dan kasa steril, dan dilakukan peresepan yaitu fluconazole tab $150 \mathrm{ml}$ $1 \mathrm{x}$ sehari untuk 14 hari, nystatin oral suspension $4 \times 4 \mathrm{ml}$ sehari yang digunakan secara kumur-buang, dan obat kumur chlorhexidine digluconate $0.12 \% 4 \mathrm{x}$ sehari dan digunakan berselang 1 jam antara kedua obat kumur. Kemudian dilakukan rujukan ke poli Infeksi HIV/AIDS dan Narkoba (IHAN) RS UNAIR.

KIE yang diberikan meliputi Informasikan tentang hasil pemeriksaan laboratorium penunjang dan mikrobiologi, Edukasi penggunaan obat jamur sistemik yang dikonsumsi 1 kali sehari secara teratur dan edukasi penggunaan penggunaan obat kumur chlorhexidine digluconate yang diberi jarak 1 jam kemudian menggunakan obat kumur nystatin yang digunakan 4 kali sehari dengan cara diteteskan, kemudian dikulum dan dibuang (3 kali setelah makan dan 1 kali sebelum tidur), Edukasi untuk tidak 
Tabel 1. Hasil pemeriksaan darah lengkap, kreatinin, dan CD4

\begin{tabular}{|c|c|c|c|}
\hline Parameter & Hasil & Nilai Rujukan & Interpretasi \\
\hline Hemoglobin (HGB) & 9,60 & $13,20-17,30 \mathrm{~g} / \mathrm{dL}$ & Rendah \\
\hline Eritrosit (RBC) & 3,48 & $4,40-5,9010^{6} / \mu \mathrm{L}$ & Rendah \\
\hline Hematokrit (PVC/HCT) & 27,70 & $40-52 \%$ & Rendah \\
\hline $\mathrm{MCV}$ & 79,60 & $80,00-100,00 \mathrm{fL}$ & Rendah \\
\hline RDW CV & 14,90 & $11,50-14,50 \%$ & Tinggi \\
\hline Eosinofil & 1,90 & $2,00-4,00 \%$ & Rendah \\
\hline Neutrofil & 75,40 & $50,00-70,00 \%$ & Tinggi \\
\hline Limfosit & 15,00 & $25,00-40,00 \%$ & Rendah \\
\hline IG\% & 1,80 & $0-0,50 \%$ & Tinggi \\
\hline IG \# & 0,14 & $0,00-0,0310^{3} / \mu \mathrm{L}$ & Tinggi \\
\hline Trombosit (PLT) & 490.000 & $150.000-440.000 / \mu \mathrm{L}$ & Tinggi \\
\hline PDW & 8,00 & $9,00-13,00 \mathrm{fL}$ & Rendah \\
\hline P-LCR & 12,50 & $15,00-25,00 \%$ & Rendah \\
\hline IPF & 1,00 & $1,10-6,10 \%$ & Rendah \\
\hline HFR & 1,50 & $0,00-1,40 \%$ & Tinggi \\
\hline LED & 54 & $0-10 \mathrm{~mm} / \mathrm{jam}$ & Tinggi \\
\hline Kreatinin & 1,27 & $0,67-1,17$ & High \\
\hline CD4 absolut & 9 & $410-1500 \mathrm{sel} / \mathrm{ul}$ & Low \\
\hline $\mathrm{CD} 4 \%$ & 0,51 & $31-60 \%$ & Low \\
\hline \multicolumn{4}{|l|}{ Pemeriksaan Mikrobiologi } \\
\hline Lokasi Pengambilan & Usap mukosa dan palatum & - & - \\
\hline Mikroskopis & Hyphae tidak bersekat & - & - \\
\hline Hasil Biakan & Candida albicans & - & - \\
\hline \multicolumn{4}{|l|}{ Pemeriksaan Anti-HIV } \\
\hline Metode 1 & Reaktif & Non reaktif & - \\
\hline Metode 2 & Reaktif & Non reaktif & - \\
\hline Metode 3 & Reaktif & Non reaktif & - \\
\hline
\end{tabular}

MCV: Mean Corpuscular Volume; RDW: Red Blood Cell Distribution Width; IG: Immature Granulocytes; PDW: Platelet Distribution Width; P-LCR: Platelet-Large Cell Ratio, IPF: Immature Platelet Fraction; HFR: High Fluorescence Ratio; LED: Laju Endap Darah; CD4: Cluster of Differentiation 4.

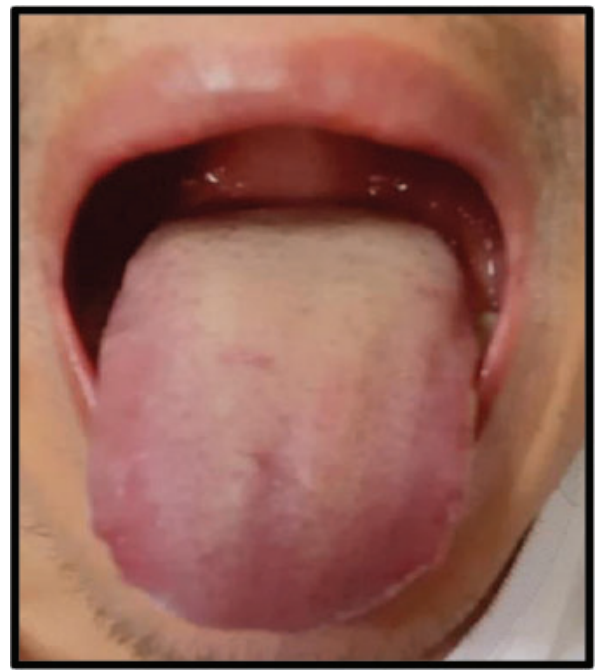

Gambar 6. Pemeriksaan intra oral 1 bulan setelah kunjungan pertama.

makan, minum dan berkumur selama 30 menit setelah penggunaan obat kumur, Edukasi untuk menghentikan obat-obatan herbal dan mengusahakan cukup istirahat dan makanan makanan yang sehat dan bergizi serta memperbanyak konsumsi buah sayur, Edukasi menjaga Oral Hygiene dengan menggosok gigi minimal 2 kali per hari, Edukasi dan motivasi pasien agar mau melanjutkan pengobatan HIV dengan rutin meminum obat ARV dan berkonsultasi dengan konselor, serta pro kontrol 1 minggu kemudian.

Pasien tidak bisa kembali kontrol ke RSGM dikarenakan kondisi yang drop dan terus menurun, merasa lemah jika berjalan, karena itu dilakukan kunjungan ke rumah pasien. Pasien sudah ke poli IHAN pada tanggal 2 januari 2020 yaitu 3 hari setelah kunjungan ke 2 sesuai rujukan yang diberikan. Obat ARV sudah mulai kembali digunakan secara rutin, sejak saat itu dan obat-obatan herbal tidak lagi digunakan. Pasien menggunakan obat jamur hanya 1 minggu sejak kontrol terakhir, dan merasa sudah tidak ada keluhan sehingga tidak digunakan lagi. Obat yang dikonsumsi dari poli IHAN adalah Efavirenz $600 \mathrm{mg}$, Zidovudine (ZDV) $300 \mathrm{mg}$ + Lamivudine (3TC) 150 mg (FDC ARV), dan juga diresepkan fluconazole $150 \mathrm{mg}$, dan Cotrimoxazole Forte $960 \mathrm{mg}$.

Pemeriksaan klinis ekstra oral masih terdapat deskuamasi, multipel, berwarna putih, bentuk dan ukuran bervariasi, batas difuse, tepi ireguler, jaringan sekitar kemerahan, tidak nyeri, terasa kering pada daerah wajah, pipi dan perioral. Pemeriksaan intra oral pada lidah dorsal dan lateral masih terdapat pseudomembran, multipel, bentuk bervariasi, berwarna putih, batas jelas, tepi ireguler, permukaan halus, daerah sekitar kemerahan, dapat dikerok, dan tidak nyeri (Gambar 5).

Pasien diresepkan kembali obat kumur nystatin yang dianjurkan untuk digunakan 4 x $4 \mathrm{ml}$ sehari selama 14 hari, kemudian diberikan KIE berupa Informasi bahwa rongga mulut belum sepenuhnya sembuh dari jamur karena masih terdapat lapisan di permukaan lidah sehingga masih harus menggunakan obat jamur, edukasi untuk kembali rutin menggunakan obat jamur sesuai anjuran yang diberikan, edukasi untuk tidak makan, minum 
dan berkumur selama 30 menit setelah penggunaan obat kumur, edukasi untuk mengusahakan cukup istirahat dan makanan makanan yang sehat dan bergizi serta memperbanyak konsumsi buah sayur, edukasi menjaga $\mathrm{OH}$ : menggosok gigi minimal $2 \mathrm{x}$ per hari, edukasi dan motivasi pasien agar terus melanjutkan pengobatan HIV dengan rutin meminum obat HIV dan berkonsultasi ke dokter sesuai anjuran yang diberikan.

Keluhan di rongga mulut pasien sudah tidak dirasakan lagi, sejak 1 minggu dari kontrol terakhir. Dan obat kumur digunakan rutin, obat antiretroviral digunakan secara teratur, berat badan dirasakan naik, dari 43 $\mathrm{kg}$ menjadi $46 \mathrm{~kg}$, nafsu makan juga sudah berusaha ditingkatkan, dan mulai optimis untuk sembuh. Pasien juga sudah rutin membersihkan rongga mulut sesuai dengan anjuran yang diberikan. Pemeriksaan klinis Intra Oral tidak ada anomali (Gambar 6).

Mengkomunikasikan ke pasien bahwa infeksi jamur pada rongga mulut telah sembuh, Menginformasikan bahwa kondisi ini dapat kambuh kembali jika daya tahan tubuh pasien yang turun dan jika tidak menjaga Oral Hygiene, edukasi untuk menghentikan penggunaan obat jamur, dan melanjutkan obat kumur antiseptik chlorhexidine gluconate, terus berkonsultasi jika ada keluhan., mengusahakan cukup istirahat, tidak stress, rutin menggunakan obat ARV, menggosok gigi minimal $2 \mathrm{x}$ per hari. Kontrol kembali bila ada keluhan.

\section{PEMBAHASAN}

Penegakan diagnosis Kandidiasis orofaring pada kasus ini yaitu melalui anamnesis, pemeriksaan klinis, dan pemeriksaan penunjang. Pada anamnesis ditemukan keluhan rasa tidak nyaman dan tebal pada rongga mulut serta kesulitan menelan. Pemeriksaan klinis ditemukan adanya pseudomembran berwarna putih atau krem yang dapat diseka dan meninggalkan area kemerahan pada dasarnya. Kandidiasis tipe pseudomembran adalah merupakan satu jenis kandidiasis yang paling sering terjadi di rongga mulut dengan tampilan klinis berupa lapisan atau plak putih multipel pada mukosa, dapat dihapus atau dikerok, tidak nyeri dan meninggalkan bekas kemerahan/ eritema, dibawah daerah yang dihapus. ${ }^{2,9}$ Hasil pemeriksaan mikrobiologi apusan mukosa diperoleh adanya hyphae dan hasil kultur jamur positif Candida albicans. Diagnosis kandidiasis mukokutan dilakukan berdasarkan pemeriksaan klinis serta didukung dengan pemeriksaan mikroskop langsung dan kultur. ${ }^{10}$

Candida albicans adalah suatu patogen oportunistik yang dapat menyebabkan infeksi pada pasien immunocompromised. Spesies Candida dapat menyebabkan infeksi baik lokal maupun sistemik pada orang orang yang memiliki faktor predisposisi dan paling sering menginfeksi pasien yang immunocompromised ataupun yang menjalani pengobatan antibiotik jangka panjang. ${ }^{11}$ Faktor resiko yang mempengaruhi seseorang rentan terhadap kandidiasis adalah faktor lokal dan sistemik yang dapat berpengaruh terhadap patogenesis Kandidiasis pada rongga mulut. Interaksi antara Candida dan host cukup kompleks melibatkan faktor host, faktor-faktor sistemik dan faktor iatrogenik. ${ }^{12}$

Faktor host yang berpengaruh terhadap terjadinya oral candidiasis adalah faktor lokal dan sistemik. Faktor-faktor lokal yang mempengaruhi adalah mukosa barier. Jika terjadi perubahan pada epitel mukosa oral seperti atrofi, hyperplasia atau displasia dapat mempromosikan terjadinya oral candidiasis. Aliran saliva yang kurang dan keasaman $\mathrm{pH}$ saliva dan penggunaan dentures. Faktor-faktor sistemik yaitu pada pasien yang immunocompromised, diabetes, HIV, leukemia dan lymphoma, faktor nutrisi, defisiensi zat besi, dan vitamin, faktor iatrogenik yaitu terapi antibiotik, terapi kortikosteroid, terapi sitotoksik dan radioterapi. ${ }^{12-14}$

Kandidiasis rongga mulut pada penderita HIV/AIDS sering disertai kandidiasis orofaring/esofagus. Kandidiasis yang paling sering terjadi di antara pasien immunocompromised dengan jumlah CD4 rendah dibawah 200 $\mathrm{sel} / \mathrm{mm}^{3}$ adalah Kandidiasis Orofaring dan/atau kandidiasis esofageal. ${ }^{2}$ Pada studi kasus ini, pasien mengalami kesulitan makan. Ini harus dicurigai sebagai kemungkinan terjadinya kandidiasis orofaring dan atau esofagus. seperti yang dilaporkan berbagai literatur keluhan kandidiasis esofagus bisa termasuk sakit saat menelan, kesulitan menelan, dan nyeri dada. ${ }^{15,16}$ Kandidiasis esofagus bisa terjadi dalam bentuk asimtomatik. Namun, kecurigaan kandidiasis esofagus tidak bisa dieliminasi tanpa pemeriksaan endoskopi. Kandidiasis esofagus adalah penyebab fatal pada Pasien HIV dengan kandidiasis oral. Oleh karena itu, memang perlu dilakukan pengobatan agresif kandidiasis oral pada pasien HIV. ${ }^{5}$

Pada pasien ini juga mengeluhkan berat badan yang turun drastis dalam 6 bulan terakhir, serta diare jangka panjang serta batuk dan sesak. Kecurigaan bahwa pasien mengidap HIV-AIDS telah ada sejak kunjungan pertama pasien, walaupun pasien masih menyangkal pada saat kunjungan pertama, sehingga kami melakukan pemeriksaan darah lengkap dan CD4 untuk mengukur jumlah limfosit T CD4 dalam darah. Manifestasi rongga mulut terutama kandidiasis oral ditemukan berkorelasi secara bermakna dengan penurunan jumlah CD4 di bawah $200 .{ }^{16}$

Pada kasus ini pasien terdiagnosis HIV berdasarkan hasil pemeriksaan serologis anti-HIV (rapid test) yang reaktif pada metode 1, 2 dan 3, serta menunjukkan beberapa tanda klinis yang menentukan fase klinis. Gangguan rongga mulut terkait HIV yang paling umum adalah kandidiasis rongga mulut yang terjadi pada $17-43 \%$ kasus dengan infeksi HIV dan lebih dari 90\% kasus dengan AIDS. ${ }^{17}$ Pada infeksi HIV kandidiasis pseudomembran pada rongga mulut dapat terjadi pada stage 3 , dan kandidiasis esofagus pada stage $4 .{ }^{18}$

Kandidiasis orofaring adalah salah satu manifestasi awal dari imunodefisiensi yang diinduksi HIV dan biasanya mempengaruhi mayoritas orang dengan infeksi HIV lanjut yang tidak diobati. Serta menunjukkan perkembangan penyakit HIV. ${ }^{2,19}$ Pemeriksaan CD4 pada pasien ini menunjukkan angka yang sangat rendah yaitu nilai $0.5 \%$ (nilai normal 31$60 \%$ ), nilai CD4 absolut $9 \mathrm{sel} / \mu \mathrm{L}$ (nilai normal 410-1590 sel/ $\mu \mathrm{L})$. CD4 bisa jadi petunjuk sebagai perkembangan awal penyakit karena jumlah CD4 menurun lebih dulu dibandingkan dengan kondisi klinis. Pengobatan ARV pada orang yang terinfeksi HIV mulai dalam tahap klinis 3 dan 4 , atau jika jumlah CD4-nya $\leq 350$ sel/ 
$\mu \mathrm{L}$. Jenis sel limfosit T CD4 merupakan target utama dari virus HIV dalam menginfeksi tubuh manusia. Semakin turun jumlah limfosit $\mathrm{T}$ CD4 dalam darah, maka akan semakin turun daya tahan tubuh seseorang. Untuk memantau progresivitas pasien terinfeksi HIV, pemeriksaan jumlah jenis sel tersebut dalam darah harus rutin dilakukan. ${ }^{20}$

Penelitian yang dilakukan oleh Afiah et al., menunjukkan bahwa pasien HIV/ AIDS biasanya mengalami keadaan limfositopenia. ${ }^{21}$ Jumlah limfosit sendiri dapat digunakan untuk memantau progresivitas HIV, yaitu penurunan yang cepat dari TLC dan $\mathrm{Hb}$ sehubungan dengan progresivitas HIV menjadi AIDS. ${ }^{22}$ Nilai rendah limfosit terjadi karena replikasi virus dalam sel merusak membran dan mengganggu fungsi sel sehingga mempengaruhi produksi limfosit. ${ }^{21}$ Pemeriksaan darah lengkap otomatis lazim dan rutin dilakukan dalam pemantauan pasien infeksi. Penurunan hemoglobin juga menandakan bertambah progresivitas infeksi HIV yang mendekati kondisi AIDS. ${ }^{20}$ Penilaian hemoglobin dan hematokrit juga penting untuk mengevaluasi anemia, karena anemia merupakan kelainan yang paling sering dijumpai pada penderita HIV/ AIDS. Anemia pada penderita HIV bisa disebabkan karena berkurangnya produksi eritrosit karena faktor yang menekan CFU-GEMM misalnya sitokin inflamasi atau HIV. ${ }^{21}$

Beberapa penyebab peningkatan kadar kreatinin dalam darah, yaitu dehidrasi, kelelahan yang berlebihan, penggunaan obat yang bersifat toksik pada ginjal, disfungsi ginjal disertai infeksi, hipertensi yang tidak terkontrol dan juga penyakit ginjal. Peningkatan ringan dalam batas normal atas merupakan indikasi terjadi perubahan subklinis fungsi ginjal dengan kadar kreatinin serum normal. Peningkatan kadar kreatinin serum dua kali lipat mengindikasikan adanya penurunan fungsi ginjal sebesar $50 \%$, dan peningkatan kadar kreatinin serum tiga kali lipat merefleksikan penurunan fungsi ginjal sebesar $75 \%{ }^{23}$

Berdasarkan definisi kasus HIV oleh WHO untuk surveilans dan revisi stadium klinis dan klasifikasi imunologi penyakit terkait HIV pada orang dewasa dan anak- anak, keluhan yang dialami oleh pasien ini dikategorikan pada tahap klinis lanjut. ${ }^{24}$ Hal ini dapat terlihat pada tanda terjadinya penurunan berat badan parah yang tidak dapat dijelaskan (> 10\% dari berat badan yang diperkirakan atau diukur), diare kronis yang tidak dapat dijelaskan selama lebih dari 1 bulan, demam persisten yang tidak dapat dijelaskan (intermiten atau konstan selama lebih dari 1 bulan, kandidiasis oral persisten, Tuberkulosis paru Infeksi bakteri parah (seperti pneumonia), dan anemia yang tidak dapat dijelaskan. ${ }^{24}$ Acquired Immunodeficiency Syndrome (AIDS) adalah penyakit yang disebabkan oleh infeksi HIV yang ditandai adanya penurunan sistem daya tahan tubuh secara progresif berakibat terjadinya infeksi oportunistik dan komplikasi lain. ${ }^{24}$

Respon imun adaptif yang sangat penting untuk perlindungan antijamur melalui ekspresi CD4+ $\mathrm{T}$ helper (Th) 1, sel (IFN $\gamma$-producing) dan sel Th17 (IL-17/IL-22-producing). Respon Th1 spesifik candida diinduksi oleh presentasi antigen di hadapan sitokin IL-12. Respon Th17 diinduksi dan dipelihara pada IL-1 dan IL-23. ${ }^{25}$ Infeksi Candida albicans dapat memicu diferensiasi sel $\mathrm{T}$ helper (Th) menuju Th17 untuk menghasilkan Interleukin 17 (IL-17) melalui aktivasi IL-23 yang diproduksi oleh sel dendritik. IL-17A memainkan peran penting dalam mobilisasi dan aktivitas fungisidal dari neutrofil. Selain itu, aktivasi IL17A melalui reseptor IL-17R di epitel menginduksi pelepasan human betadefensin 2 (HBD-2). HBD-2 adalah bagian dari sistem kekebalan bawaan yang memainkan peran dalam perekrutan dan aktivasi neutrofil untuk melawan Candida albicans. $^{26,27}$

Obat-obatan antifungal yang digunakan untuk perawatan kandidiasis terbagi menjadi beberapa kategori yaitu: polyenes (nystatin dan amphotericin $B)$; penghambat biosintesis argosterol Azole (miconazole, clotrimazole, ketoconazole, itraconazole dan fluoconazole), allyaminesthiocarbamates, dan morpholines; dan analog DNA 5-fluorocytosine, dan caspofungins. Pemilihan perawatan antifungal tergantung pada lesi dan status imunologis pasien. Ada tiga target utama obatobatan antifungal pada Candida yaitu sel membran, dinding sel, dan asam nukleid. ${ }^{16}$ Golongan obat anti jamur topikal yang digunakan pada kandidiasis antara lain: imidazole dan poliene. ${ }^{10}$

Poliena adalah obat fungisida yang bekerja melalui pengikatan langsung ke ergosterol di dalam membran sel jamur, menyebabkan kebocoran isi sitoplasma yang menyebabkan kematian sel jamur. Larutan nistatin atau amfoterisin B digunakan selama 4 minggu. Anti jamur sistemik biasanya diindikasikan pada kasus penyakit yang menyebar dan / atau pada pasien dengan gangguan sistem imun. Azoles adalah obat fungistatik yang menghambat enzim jamur lanosterol demethylase yang bertanggung jawab untuk sintesis ergosterol. ${ }^{16}$

Dalam penggunaan nystatin suspensi, Patil $S$ et al., mengklaim bahwa dosis suspensi nistatin adalah 400.000 - 600.000 unit, empat kali sehari, untuk tujuh sampai empat belas hari. ${ }^{16}$ Pada pasien ini kami menggunakan dosis 400.000 unit sebanyak 4 kali sehari. Kurang lebih selama 6 minggu. Kami menganjurkan untuk menambah waktu pemakaian 1 minggu setelah gejala hilang.

Spesies Candida berkoloni di mukosa mulut melalui adhesi ke sel epitel, pembentukan tabung germinal, dan hidrofobisitas permukaan sel relatif. Oleh karena itu, obat topikal yang diserap ke dalam epitel mulut diperlukan untuk membunuh hifa jamur yang tumbuh di dalam jaringan. Dalam penelitian sebelumnya, durasi pengobatan nistatin bervariasi dari 1 sampai 6 minggu. Penelitian sebelumnya mengusulkan bahwa larutan nistatin perlu digunakan setidaknya 1 minggu setelah gejala hilang, biasanya selama 4 minggu untuk pengobatan utama kandidiasis oral. Selain itu, dalam kasus berulang, durasi pengobatan harus setidaknya 4 sampai 6 minggu. ${ }^{5}$

Obat-obatan HAART yang diberikan pada pasien ini meliputi Efavirenz $600 \mathrm{mg}$, Zidovudine (ZDV) $300 \mathrm{mg}+$ Lamivudine (3TC) $150 \mathrm{mg}$ (FDC ARV), dan juga diresepkan fluconazole $150 \mathrm{mg}$, dan Cotrimoxazole Forte $960 \mathrm{mg}$. Standar perawatan saat ini untuk pengobatan Infeksi HIV adalah terapi tiga obat dengan dua nukleotida atau penghambat transkriptase balik nukleotida (NRTI/ 
NtRTI) dalam kombinasi dengan NonNucleoside Reverse Transcriptase Inhibitor (NNRTI) atau protease inhibitor (PI). Pada pasien dengan jumlah CD4, 100 / ml atau AIDS lanjut, pengobatan ART harus dipertimbangkan sedini mungkin. ${ }^{28}$

Tantangan perawatan pada pasien ini adalah karena sikap pasien yang masih menyangkal mengidap HIV/AIDS sehingga tidak taat dan tidak teratur menggunakan obat. Perawatan HAART juga kompleks, karena adanya beragam kombinasi jumlah pil, frekuensi dosis, pembatasan makan, dan lain-lain yang harus dijalankan secara rutin. ${ }^{29}$

\section{SIMPULAN}

Berdasarkan anamnesis, pemeriksaan klinis, dan pemeriksaan penunjang, diagnosis dari kasus ini yakni Kandidiasis orofaring dengan tipe kandidiasis pseudomembran. dengan etiologi penyakit sistemik yakni HIV-AIDS dengan nilai CD4 yang sangat rendah. Keberhasilan perawatan tergantung pada terapi yang terintegrasi antara dokter gigi dan dokter penyakit dalam. Kepatuhan pasien dalam mengikuti instruksi dokter dan kepercayaan pasien kepada dokter yang merawat adalah kunci dalam keberhasilan perawatan yang dilakukan.

\section{KONFLIK KEPENTINGAN}

Penulis menyatakan tidak terdapat konflik kepentingan terkait publikasi dari laporan kasus ini.

\section{PERSETUJUAN ETIK}

Pasien telah menandatangani lembar informed consent dan setuju bahwa foto klinis dari pasien akan dipublikasikan di jurnal ilmiah kedokteran berdasarkan pedoman COPE dan ICMJE.

\section{PENDANAAN}

Laporan kasus ini tidak mendapat dana hibah dari pemerintah ataupun lembaga swasta lainnya.

\section{KONTRIBUSI PENULIS}

Seluruh penulis berkontribusi terhadap laporan kasus ini baik dari perencanaan, pencarian data pasien, analisis data pasien, dan penyusunan naskah publikasi.

\section{DAFTAR PUSTAKA}

1. Majid ZSA, Taher EM. A Case Report of Pseudomembranous Candidiasis Induced by Long Term Systemic Corticosteroid Therapy. Int J Dent Health Sci 2015;2(2):454-458.

2. Mukherjee M, Basak S, Guha SK, Dutta D, Chakraborty A. Oropharyngeal Candidiasis in HIV/AIDS : A Hospital Based Co-Relation Study. International Journal of Research In Medical and Health Sciences. 2014;4(4):19-23.

3. Patil S, Majumdar B, Sarode SC, Sarode GS, Awan KH. Oropharyngeal Candidosis in HIVInfected Patients-An Update. Front Microbiol. 2018;9:980

4. Nelwan EJ. HIV Infection in Indonesia. Acta Medica Indonesiana. 2017;49(3):193-194.

5. Murtiastutik D, Prakoeswa CRS, Tantular IS. Fluconazole Resistant Oral Candidiasis on HIV Patient-What Other Drug can We Choose? A Case Report. J Pure Appl Microbiol. 2020;14(1):31-36.

6. Aškinytė $\mathrm{D}$, Matulionytè $\mathrm{R}$, Rimkevičius A. Oral manifestations of HIV disease: A review. Stomatologija. 2015;17(1):21-28.

7. Vargas KG, Joly S. Carriage frequency, intensity of carriage, and strains of oral yeast species vary in the progression to oral candidiasis in human immunodeficiency virus-positive individuals. J Clin Microbiol. 2002;40(2):341-350.

8. Bodhade AS, Ganvir SM, Hazarey VK. Oral manifestations of HIV infection and their correlation with CD4 count. J Oral Sci. 2011;53(2):203-211.

9. Rodrigues CF, Rodrigues ME, Henriques M. Candida sp. Infections in Patients with Diabetes Mellitus. J Clin Med. 2019;8(1):76.

10. Katoh T. Guidelines for diagnosis and treatment of mucocutaneous candidiasis. 2009;50(4):207212.

11. Rathod T, Padalia H, Chanda S. Anticandidal and synergistic anticandidal activity and chemical composition of citrus reticulate and Azadirachta indica essential oil. Journal of Pharmacy. 2017;7(9):52-71

12. Van Wyk C, Steenkamp V. Host factors affecting oral candidiasis. South Afr J Epidemiol Infect. 2011;26(1):18-21

13. Chu X. Oral Candidiasis: relation to systemic diseases and medications. Dentistry 3000. 2017;5(1):1-9.

14. Rathod P, Punga R, Dalal V, Rathod D. Oral Candidiasis-Widely Prevalent, Frequently Missed. International Journal of Scientific Study. 2015;3(6):193-194.

15. Williams D, Lewis M. Pathogenesis and treatment of oral candidosis. J Oral Microbiol. 2011;3:10.3402/jom.v3i0.5771.

16. Patil S, Rao RS, Majumdar B, Anil S. Clinical Appearance of Oral Candida Infection and Therapeutic Strategies. Front Microbiol. 2015;6:1391.

17. Ranganathan K, Reddy BV, Kumarasamy N, Solomon S, Viswanathan R, Johnson NW. Oral lesions and conditions associated with human immunodeficiency virus infection in 300 south Indian patients. Oral Dis. 2000;6(3):152-157.

18. Frimpong P, Amponsah EK, Abebrese J, Kim SM. Oral manifestations and their correlation to baseline CD4 count of HIV/AIDS patients in Ghana. J Korean Assoc Oral Maxillofac Surg. 2017;43(1):29-36

19. Shetti A, Gupta I, Charantimath SM. Oral Candidiasis: Aiding in the Diagnosis of HIV-A Case Report. Case Rep Dent. 2011;2011:929616.

20. Wande IN, Fuadi MR, Hadi S. The Correlation between total lymphocyte count, hemoglobin levels, lymphocyte/leukocyte ratio (LLR), and lymphocyte/neutrophil ratio (LNR) to $\mathrm{CD} 4$ levels in patients with Human Immunodeficiency Virus infection at Sanglah Hospital. Bali Medical Journal. 2019;8(2):337341.

21. Afiah A, Arif M, Hardjoeno. Profil tes darah rutin dan jumlah limfosit total pada penderita HIV/AIDS. Indonesian Journal of Clinical Pathology and Medical Laboratory. 2007;13(2):56-59.

22. Lau B, Gange SJ, Phair JP, Riddler SA, Detels $\mathrm{R}$, Margolick JB. Use of total lymphocyte count and hemoglobin concentration for monitoring progression of HIV infection. J Acquir Immune Defic Syndr. 2005;39(5):620-625.

23. Rampa E, Prastyawati R, Sinaga H. Pemeriksaan Kadar Ureum dan Kreatinin Pasien HIV yang Mendapatkan Terapi ARV di Puskesmas Harapan Sentani Kabupaten Jayapura Papua. Jurnal Penelitian Kesehatan Suara Forikes. 2019;10(3):223-226

24. Teck R, Ascurra O, Gomani P, Manzi M, Pasulani O, Kusamale J, et al. WHO clinical staging of HIV infection and disease, tuberculosis and eligibility for antiretroviral treatment: relationship to CD4 lymphocyte counts. Int J Tuberc Lung Dis. 2005;9(3):258-62.

25. van de Veerdonk FL, Netea MG, Joosten LA, van der Meer JW, Kullberg BJ. Novel strategies for the prevention and treatment of Candida infections: the potential of immunotherapy. FEMS Microbiol Rev. 2010;34(6):1063-1075.

26. Rahayu RP, Prasetyo RA, Purwanto DA, Kresnoadi U, Iskandar RPD, Rubianto M. The immunomodulatory effect of green tea (Camellia sinensis) leaves extract on immunocompromised Wistar rats infected by Candida albicans. Vet World. 2018;11(6):765770 .

27. Jiang S. Immunity against Fungal Infections. Immunology and Immunogenetics Insights. 2016:8:3-6.

28. Kwara A, Flanigan TP, Carter EJ. Highly active antiretroviral therapy (HAART) in adults with tuberculosis: current status. Int $J$ Tuberc Lung Dis. 2005;9(3):248-257.

29. Heath KV, Singer J, O'Shaughnessy MV, Montaner JS, Hogg RS. Intentional nonadherence due to adverse symptoms associated with antiretroviral therapy. J Acquir Immune Defic Syndr. 2002;31(2):211-217.

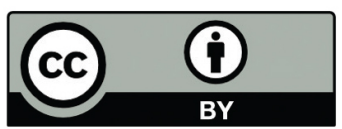

This work is licensed under a Creative Commons Attribution 